\title{
Supplementation with nutraceuticals produces changes in working horse's blood parameters but not in their body composition
}

\author{
Hélio Cordeiro Manso Filho ${ }^{1,4}$, José Mário Girão Abreu², Helena Emília Cavalcanti da Costa Cordeiro Manso ${ }^{3}$,
}

\author{
Tito Alves Santiago 4 Fernando Jorge Rodrigues Magalhães ${ }^{4}$
}

\begin{abstract}
Background: There is little scientific data about the effects of continuous supplementation with nutraceuticals over horse's health and performance. Horse owners and veterinarians are still using supplements for horses without any kind of evaluations. At the Brazilian market is possible to buy hundreds of different products, but there is not private or state regulation over production and quality of these products. The absence of information about quality and efficacy of these products may contribute to mistakes in horse's nutrition program. The objective of this research was to determine the effect of supplementation with a combination of nutraceuticals over some blood parameters (red cell count, total plasma proteins, free plasma glutamine and glutamate) and components of body composition in working horses.

Materials, Methods \& Results: There were 19 gelding horses, divided in two groups: nutraceutical (NUTR; n=10) and placebo (PLAC; n=9). Both groups received equivalent feeding regimens in regard to concentrate and grass, and did similar exercise program. NUTR group received their pellets with nutraceuticals, and PLAC group received a placebo during the morning meal. There is no visual difference between nutraceutical and placebo pellets. Body composition determination and blood collection were taken in three periods: pre-test, after 4 and 12 weeks of supplementation. Body composition was determined after evaluation of horse's body mass by electronic scale associated with measurement of rump fat by ultrasound. Results showed that there were no significant changes in body composition during 12 weeks of supplementation in both groups, which had percentage of body fat around $13 \%$. However, supplementation with nutraceutical produced significant changes $(\mathrm{P}<0.05)$ in some blood parameters in NUTR group. This group had large red cell count, hematocrit and blood glutamine concentration when compared with PLAC group after 12 weeks of supplementation. Blood glutamate concentration did not change in both groups.

Discussion: Supplementation with nutraceutical or placebo did not produce illness or other nutritional problem in the experimental horses during 12 weeks. Also, because the nutraceutical and placebo pellets were visually similar to horse's grain, the experimental animals did not have problems to eat all feed during 12 weeks. During this period it was observed that NUTR group had some improvement of the blood parameters when compared with PLAC group $(\mathrm{P}<0.05)$, without adaptation or changes in body mass. Frequently supplement's advertises use improvement in the body mass as major effects of their products, but some of these effects are subjective because they use body score to show supplementation's results. Increase in hematocrit $(>16 \%)$, total plasma protein $(>7 \%)$ and free plasma glutamine $(>20 \%)$ observed in NUTR group will contribute to horse's performance since it is positive action on red blood indexes and plasma amino acid concentration, contributing to the well-being of this horse group. Increase in blood glutamine concentration observed in NUTR group without improvement of body composition was not expected because this amino acid is produced mainly by skeletal muscle. Increase in fat-free mass frequently is associated with improvement of blood glutamine concentration. Finally, initial elevation in few parameters in PLAC group at 4 weeks of supplementation probably was associated with improvement of general management practices. In conclusion, Supplementation with a nutraceutical combination, for 12 weeks, produces changes in the concentration of some blood parameters, but it didn't modify the corporal composition. The elevation of those components can favor the transport of oxygen and nutrients in tissues leading to improvement in the horse performance.
\end{abstract}

Keywords: equine, exercise, amino acids, hematology, fat-free mass.

Descritores: cavalo, suplementação, amino-ácidos.

Received: January 2010

www.ufrgs.br/actavet

Accepted: April 2010

${ }^{1}$ Departamento de Zootecnia, Núcleo de Pesquisa Equina, Universidade Federal Rural de Pernambuco (UFRPE). Rua D. Manuel Medeiros s/n, Dois irmãos, CEP 52171-900 Recife, PE, Brasil. '²aculdade de Medicina Veterinária, Universidade Estadual do Ceará (UECE), Fortaleza, CE, Brasil.. ${ }^{3}$ BIOPA - Laboratório de Biologia Molecular Aplicada à Produção Animal, UFRPE. ${ }^{4}$ Programa de Pós-graduação em Ciência Veterinária, UFRPE. CORRESPONDÊNCIA: H.C. Manso Filho [hmanso@dz.ufrpe.br - Fax: +55 (81) 3320-6551]. 


\section{INTRODUCTION}

The equine market has been moving great financial sums in Brazil and gaining attention from the pharmaceutical and nutrition industries, which produce different supplements for horses. However, there are few tests and scientific validation to prove the effectiveness of these supplements for this group of animals $[3,6,24]$.

Great parts of supplement products in the Brazilian market are a combination of hematinics associated with minerals and, sometimes, also includes amino acids and nutraceuticals. The term nutraceutical has been applied for compounds or bioactive nutrients that promote health $[2,12]$. Moreover, it is believed that combinations of different nutraceuticals or supplements are more effective than one single supplement, once metabolism depends on the performance of several compounds simultaneously [16,24].

The production of industrial equine's supplements still lacks of rigorous quality tests and, in many times, there is no demonstration of effectiveness and safety of these products [3, 24]. Even for animals of superior genetics there's a need for special feeding and training programs to become winners [25], which stimulates the search of formulations that improve horse's performance and health. The objective of this research was for evaluating the effects of the supplementation with a nutraceuticals combination over blood parameters and of body composition of working horses.

\section{MATERIALS AND METHODS}

The methodology used in this research was approved by the Ethics Committee of the Ceará State University ( $\mathrm{N}^{\circ}$ 06093339-5).

\section{Experimental animals and management practices}

Nineteen patrol horses were used (mixed breed (Nordestino x Crioulo), geldings, (clinically healthy) from the Military Police of Ceara State. They were randomly divided into two groups: Nutraceutical (NUTR) ( $\mathrm{n}=10$; age 13,8 \pm 5,4 years) and Placebo (PLAC) ( $=9$; age 9,2 \pm 4,6 years). The animals were housed in individual boxes, with free access to the water and mineralized salt. The routine consisted of patrol services of 8 hours that include transportation to the working place, moving at walk or trot, 3 to 4 times a week, in varied periods of the day. In the days of rest they had free access to areas of native pasture. Both groups of animals were individually fed with grass (Pennisetum purpureum; $9.0 \mathrm{~kg} / \mathrm{day} /$ animal, divided in three equivalent portions, every 8 hours) and with commercial pellets ${ }^{1}$ (4.0kg/day/animal, divided in two portions, every 12 hours).

\section{Supplementation program}

Animals received their supplements in morning meal, where NUTR receiving $90 \mathrm{~g} /$ day of nutraceutical pellets $^{2}$, while PLAC receiving 90g/day of the placebo ${ }^{3}$ (just the vehicle used in the supplement, without nutraceuticals). The horse keepers were not informed about the characteristics of the two supplements, which were pellets macroscopically similar. Food analysis was made at the Animal Nutrition Laboratory of Ceará Federal University.

\section{Sample collection}

Evaluations of the body composition and collection of blood samples were taken in pre-test, and 4 and 12 weeks after supplementation, in both groups. After overnight fastening, the blood was drawn from the jugular vein in vacutainer type tubes with anticoagulant (heparin, green top) and divided in two aliquots: one for amino acid determination and another for blood analysis. For determination of free plasma glutamine and glutamate an aliquot of heparinized blood $(0.5 \mathrm{~mL})$ was mixed with $0.5 \mathrm{~mL}$ of cold percloric acid $10 \%$, and soon after neutralized with potassium hydroxide $0.5 \mathrm{M}$. Then the samples were frozen to $20^{\circ} \mathrm{C}$ until analyses for the determination of amino acids [10]. Analyses of blood [red blood cells (RBC), hemoglobin $(\mathrm{Hb})$, hematocrit $(\mathrm{Ht})$ and total plasma proteins (TPP) were processed with the usual laboratory techniques. Results of the pre-test are described combined because all the 19 horses were submitted to the same management practices and to the same program of exercises (trainings and patrols). Personal involved with blood and amino acids analysis was not capable to identify samples from nutraceutical or placebo treatment.

\section{Body composition determination}

Body composition was determined from a method described in the literature [23], in which the weight of the animal is used, obtained in an electronic scale, in association with the determination of the fat thickness at the rump by ultrasound ${ }^{4}$. This consists in the placement of the $5.0 \mathrm{MHz}$ probe of the ultrasound in a medium line between the tip of the ileum and of the isquium, about $10 \mathrm{~cm}$ of the medium 
Filho, H.C.M.F., Abreu, J.M.G., Manso, H.E.C.C.C.M., Magalhães, F.J R. 2010 Supplementation with Nutraceuticals Produces Changes in Working Horse's Blood Parameters but not in their Body Composition. Acta Scientiae Veterinariae. 38(3): 295-300.

line of the body. Finally body fat percentage (FP) can be calculated by the following equation: $\mathrm{FP}=$ $8.64+(4.7 \times$ fat thickness $)[23]$.

\section{Statistical analysis}

The results were submitted to the analysis of the variance (ANOVA) through the computation program SigmaStat ${ }^{\circ} 3.0^{5}$ for the operating system Windows $\AA$ XP. The method of Holm-Sidak was used for all pair wise multiple comparison and level of significance established in $5 \%$. The results were expressed on average $+/$ - standard error medium.

Table 1. Results of the blood parameters (red cell, hematocrit, hemoglobin, total plasma protein, glutamine, glutamate) and the components of body composition (body mass, fat-free mass, fat mass, percentage of body fat and rump fat thickness) in experimental horses (mixed breed Nordestino x Crioulo, geldings, ages: nutraceutical group 13,8 \pm 5,4 years, placebo group $9,2 \pm 4,6$ years) in Ceará, supplemented with placebo or nutraceutical during 12 weeks.

\begin{tabular}{|c|c|c|c|c|c|}
\hline \multirow[t]{2}{*}{ Parameter } & \multirow{2}{*}{$\begin{array}{l}\text { Pre-test } \\
\text { Control } \\
(n=19)\end{array}$} & \multicolumn{2}{|c|}{$\begin{array}{c}\text { Placebo } \\
(n=9)\end{array}$} & \multicolumn{2}{|c|}{$\begin{array}{c}\text { Nutraceutical } \\
((n=10)\end{array}$} \\
\hline & & 4 weeks & 12 weeks & 4 weeks & 12 weeks \\
\hline $\begin{array}{l}\text { Red cell } \\
\left(\mathbf{x} 10^{6} / \mathrm{mm}^{3}\right) \\
\text { Hemoglobin } \\
\text { (g/dL) } \\
\text { Hematocrit } \\
(\%)\end{array}$ & $\begin{array}{c}6.6 \pm 0.1 \\
\mathbf{c} \\
10.4 \pm 0.5 \\
\mathbf{b} \\
32.2 \pm 1.3 \\
\mathbf{b c}\end{array}$ & $\begin{array}{c}6.9 \pm 0.1 \\
\mathbf{b c} \\
14.7 \pm 0.5 \\
\mathbf{a} \\
\begin{array}{c}36.3 \pm 1.3 \\
\mathbf{a b}\end{array}\end{array}$ & $\begin{array}{c}7.2 \pm 0.1 \\
\mathbf{b} \\
11.6 \pm 0.6 \\
\begin{array}{c}\mathbf{b} \\
31.0 \pm 1.6 \\
\mathbf{c}\end{array}\end{array}$ & $\begin{array}{c}7.0 \pm 0.1 \\
\mathbf{b} \\
15.3 \pm 0.7 \\
\underset{\mathbf{a}}{38.1 \pm 1.7} \\
\mathbf{a}\end{array}$ & $\begin{array}{c}7.7 \pm 0,1 \\
\mathbf{a} \\
13.6 \pm 0.7 \\
\begin{array}{c}\mathbf{a} \\
38.7 \pm 1.7 \\
\mathbf{a}\end{array}\end{array}$ \\
\hline 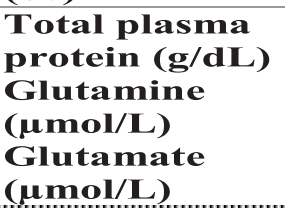 & $\begin{array}{c}6.5 \pm 0.3 \\
\mathbf{c} \\
433.3 \pm 23.4 \\
\mathbf{b} \\
141.0 \pm 11.5 \\
. . . . \cdots\end{array}$ & $\begin{array}{c}8.5 \pm 0.3 \\
\mathbf{a} \\
410.0 \pm 13.1 \\
\mathbf{b} \\
116.2 \pm 5.6 \\
\mathbf{a b}\end{array}$ & $\begin{array}{c}6.7 \pm 0.3 \\
\mathbf{b c} \\
457.5 \pm 47.1 \\
\mathbf{b} \\
133.8 \pm 9.9 \\
\mathbf{a b}\end{array}$ & $\begin{array}{c}8.6 \pm 0.4 \\
\mathbf{a} \\
447.1 \pm 14.0 \\
\mathbf{b} \\
101.4 \pm 9.0 \\
\mathbf{b}\end{array}$ & $\begin{array}{c}7.8 \pm 0.5 \\
\mathbf{a b} \\
578.0 \pm 57.0 \\
\mathbf{a} \\
113.4 \pm 4.7 \\
\mathbf{b}\end{array}$ \\
\hline $\begin{array}{l}\text { Body mass } \\
\text { (Kg) }\end{array}$ & $321.2 \pm 7.5$ & $315.1 \pm 6.6$ & $319.8 \pm 6.4$ & $323.8 \pm 12.1$ & $328.8 \pm 12.5$ \\
\hline $\begin{array}{l}\text { Fat-firee } \\
\text { mass (Kg) }\end{array}$ & $278.0 \pm 6.5$ & $274.2 \pm 5.5$ & $277.0 \pm 6.5$ & $278.0 \pm 10.6$ & $284.4 \pm 11.0$ \\
\hline $\begin{array}{l}\text { Fat mass } \\
(\mathbf{K g})\end{array}$ & $43.1 \pm 1.3$ & $41.0 \pm 2.6$ & $42.9 \pm 1.5$ & $45.8 \pm 2.3$ & $44.6 \pm 2.8$ \\
\hline $\begin{array}{l}\text { Percentage of } \\
\text { body fat }(\%)\end{array}$ & $13.4 \pm 0.3$ & $13.0 \pm 0.7$ & $13.4 \pm 0.5$ & $14.1 \pm 0.5$ & $13.5 \pm 0.6$ \\
\hline $\begin{array}{l}\text { Rump fat } \\
\text { thickness }(\mathrm{cm})\end{array}$ & $1.02 \pm 0.06$ & $0.92 \pm 0.15$ & $1.02 \pm 0.11$ & $1.17 \pm 0.10$ & $1.03 \pm 0.13$ \\
\hline
\end{tabular}

Observations: Same latter, at same figures, represents $\mathrm{P}>0,05$ by Holm-Sidak test.

Table 2. Nutrient analysis of nutraceutical supplement, placebo supplement, commercial pellets and elephant grass used for experimental horses (mixed breed Nordestino x Crioulo, geldings, age 9-13 years), during 12 weeks in Ceará.

\begin{tabular}{|c|c|c|c|c|}
\hline \multirow[t]{2}{*}{ Nutrient analysis } & \multicolumn{4}{|c|}{ Experimental food } \\
\hline & $\begin{array}{l}\text { Nutraceutical } \\
\text { supplement }\end{array}$ & $\begin{array}{c}\text { Placebo } \\
\text { supplement }\end{array}$ & $\begin{array}{l}\text { Comercial } \\
\text { pellets }\end{array}$ & $\begin{array}{l}\text { Elephant } \\
\text { Grass }\end{array}$ \\
\hline Dry matter $(\%)$ & 88.50 & 87.50 & $\begin{array}{c}89.60 \\
(88.0 \mathrm{~min})\end{array}$ & 12.40 \\
\hline Crude protein $(\%)$ & $\begin{array}{c}22.50 \\
(18.0 \mathrm{~min})\end{array}$ & 20.50 & $\begin{array}{c}18.50 \\
(14.0 \mathrm{~min})\end{array}$ & 9.80 \\
\hline Eter extract $(\%)$ & $\begin{array}{l}8.25 \\
(4.0 \mathrm{~min})\end{array}$ & 7.10 & $\begin{array}{c}7.35 \\
(2.0 \min )\end{array}$ & -- \\
\hline Crude fiber $(\%)$ & $\begin{array}{c}3.70 \\
(5.5 \max )\end{array}$ & 3.23 & $\begin{array}{c}3,30 \\
(10.0 \max )\end{array}$ & ---- \\
\hline $\begin{array}{l}\text { Neutral detergente fiber }(\%) \\
\text { Acid detergente fiber }(\%)\end{array}$ & $\begin{array}{l}17.25 \\
6.28\end{array}$ & $\begin{array}{l}3.35 \\
7.12\end{array}$ & $\begin{array}{l}42.29 \\
13.14\end{array}$ & $\begin{array}{l}74.50 \\
50.20\end{array}$ \\
\hline $\operatorname{Ash}(\%)$ & $\begin{array}{c}5.20 \\
(5.5 \max )\end{array}$ & 13.31 & $\begin{array}{c}12.07 \\
(12.0 \max )\end{array}$ & ---- \\
\hline Gross energy (kcal/g) & 3.90 & 3.64 & 4.23 & ---- \\
\hline
\end{tabular}

Observation: values between parenthesis represents guarantee levels for each product; min=minimum, max=maximum 
Hematinic indexes (IH) changed in both groups along the experiment, but only in the NUTR group the $\mathrm{RBC}, \mathrm{Hb}$ and $\mathrm{Ht}$ were elevated in the 12th week, when compared with the values seen in the pre-test $(\mathrm{P}<0.05)$ (Table 1). Hemoglobin had its highest concentration in the 4th week in NUTR group ( 15.3g\%), however, RBC and Ht had their higher values at the 12 th week, $\sim 7.7 \times 10^{6} / \mathrm{mm}^{3}$ and $\sim 38.7 \%$, respectively, in NUTR group. The lowest values of those blood parameters were detected in the pre-test for RBC $\left(\sim 6.6 \times 10^{6} / \mathrm{mm}^{3}\right)$ and $\mathrm{Hb}(\sim 10.4 \mathrm{~g} / \mathrm{dL})$ and in PLAC group for $\mathrm{Ht}(\sim 30.9 \%)$.

The increase of Glutamine [Gln] $(\mathrm{P}<0.05)$ was observed in NUTR group that had elevated Gln $(\sim 557 \mu \mathrm{mol} / \mathrm{L})$ and reduced Glutamate [Glu] $(\sim 113 \mu \mathrm{mol} /$ L) at the end of the 12 weeks of supplementation (Table 1). Finally, in this research TPP modified in both groups with supplementation $(\mathrm{P}<0.05)$ (Table 1), though in NUTR group the largest concentration was observed in the 4 th week $(\sim 8.6 \mathrm{~g} / \mathrm{dL})$ followed by PLAC group in the same week $(\sim 8.4 \mathrm{~g} / \mathrm{dL})$.

\section{DISCUSSION}

Supplementation with nutraceutical combination produced significant changes in $\mathrm{HI}$ that contributes to horse's performance. The values for $\mathrm{RBC}, \mathrm{Hb}$ and $\mathrm{Ht}$ observed at the 4th week were already elevated in both groups (NUTR and PLAC), through in the 12th week the animals of those groups seemed to have obtained a new homeostasis level, with lower values than observed in the 4th week, mainly in PLAC group that practically returned to pre-test values. These initial variations in $\mathrm{HI}$ probably were produced by improvement of the management techniques, principally nutritional supplementation. The values of $\mathrm{RBC}$ and of $\mathrm{Hb}$ in pretest were the lowest viewed during the whole test, but even so they were still in the range of the values of the normality for horses [13], as well as all other blood parameters for the NUTR and PLAC groups.

The averages of HI at 12th week of NUTR group were larger when compared to the averages observed in the adult horses to field and in training [19], while the ones in PLAC group were inferior. The animals used in the study were a mixed of Crioulo breed with Nordestino breed, so for that the comparison with Crioulo breed studies are pertinent [19], while the study with Thoroughbred that used a great number of animals and is worldwide accepted should be used with precaution [13]. There are some difficulties when there is a comparison among results of different studies because handling and training conditions can be variable, however comparison with pre-test values are important and produce better indications of the variations along the research. Finally, it is important to remember that elevation in the HI seen in the NUTR group, which uses nutraceuticals for 12 weeks, may improve horses' performance during the patrols and other exercises. The elevation of IH already at 4th week and in both groups should be also associated with the intensification of the animal's handling developed by the horse keepers, caused by the increase of animal's accompaniment by the researchers.

Another important finding of this research was the elevation of Gln and reduction of Glu that may have positive implications for the working horse. Glutamine is considered conditionally essential amino acid and is largely metabolized by cells of the immunologic system and enterocytes [12, 15]. This amino acid is formed from the reaction of glutamate with the ammonia and mediated by glutamine synthetase in different tissues, mainly by skeletal muscle that produces and stores it in large scale [10, 20]. In several species, reduction of Gln is associated to acute and chronic illnesses and, therefore the maintenance of Gln elevated can be important for horse's health since this amino acid is broadly consumed by kidneys cells, enterocytes and immune system cells $[4,12,14,15,20,21]$. Other factors are also positively affected with the enhance of the Gln, as for instance the increase of the muscular anabolism, that in an indirect way can be used as an indicative of the positive effects of the supplementation with BCAA, and an improvement in the acid-base balance $[12,20,22,24]$. Finally, Gln contributes to the synthesis of glutatione that is an important intracellular antioxidant agent that acts reducing the free radicals production during the exercises and stress [17].

The amount of Gln in the feeds were not determined though almost the whole Gln presented in it is used by the enterocytes [18], hindering the observation of the possible effects of the oral supplementation of that amino acid [4]. The NUTR group received supplementation with branched chain amino acid (BCAA) and with it stimulating the muscular anabolism and followed by increases in Gln storage and production, by skeletal muscle, and use of Glu present in the blood [20]. 
Evaluations of TTP concentration are one important tool to understand blood volume and nutrient exchange between different tissues [1]. An initial elevation can be credited by an improvement of the handling of the experimental animals, though at the end of the 12th week NUTR group $(\sim 7.7 \mathrm{~g} / \mathrm{dL})$ still presented significantly values superiors to the pre-test $(\sim 6.5 \mathrm{~g} / \mathrm{dL})$ what didn't happen in the same period with the PLAC group $(\sim 6.7 \mathrm{~g} / \mathrm{dL})$. The average of TPP was inferior then the average values described in Crioulo horses [19], but the averages obtained in NUTR and PLAC groups were inside the normal values for the species [13]. It should be observed that the elevation of TPP, contributes to regulate the blood volume and also it might have contributed to the reduction of the concentration of the erythrocytes in the 12th week when compared with to 4th week and improving transport of nutrients between different tissues.

Many supplements for horses usually are designed to improve corporal condition and/or muscular mass, even though changes in the components of the body composition (free-fat mass and fat mass) of the horses with the use of supplement were not identified $(\mathrm{P}>0.05)$, differently from observed in the research observed with older horses using the same nutraceuticals combination [9]. Animals used in this research had some differences in their corporal mass, but that was not significant ( $\mathrm{P}>0.05)$. In contrast to the determination of the corporal score, the characterization of the corporal composition is objective and capable of characterizing the components of the body and help to adopt correct management techniques [7]. The animals of both groups at the end of the experiment had a percentage of body fat around $13 \%$, which were superior to the ones of racehorses [8] but they resembled others studies with older horses ( $>20$ years old) [9] and with fourgaited horses, which do typical aerobical exercise, in same area in Brazil [11].

\section{CONCLUSIONS}

Supplementation with a nutraceutical combination, for 12 weeks, produced changes in the concentration of some blood parameters, but it didn't modify the corporal composition. The horse group that received supplementation with nutraceutical had $\mathrm{Ht}$, TPP and Gln increased by $16.0 \%, 7.0 \%$ and $20.0 \%$, respectively, when compared with pre-test value. The elevation of those components can favor the transport of oxygen and nutrients in tissues leading to improvement in the horse performance.

This project received support from IRCA Nutrição Animal and from Esquadrão de Cavalaria "Cel Moura Brasil” from Ceará State Police.

Sources and Manufacturers

${ }^{1}$ Fri-Ribe 14/65. Rações Fri-Ribe S.A., Maracanau, CE, Brasil.

${ }^{2}$ Irca Vit EQ Athletic. IRCA Nutrição Animal S.A., Carpina, PE, Brasil.

${ }^{3}$ Placebo. IRCA Nutrição Animal S.A. Carpina, PE, Brasil. ${ }^{4}$ Scanner 450, Pie Medical Linear Array, Philipsweg 1, Maastricht, Holland.

${ }^{5}$ SigmaStat 3.0 for Windows. SPCC Inc., Jandel Scientific, San Rafael, California, EUA.

\section{REFERENCES}

1. Brosnan J.T. 2003. Interorgan amino acid transport and its regulation. Journal of Nutrition. 133(6 Suppl 1): 2068S-2072S.

2. Elliott R. \& Ong T.J. 2002. Nutritional genomics. British Medical Journal. 324(7351): 1438-1442.

3. Geor R.J. 2006. The role of nutritional supplements and feeding strategies in equine athletic performance. Equine and Comparative Exercise Physiology. 3(3): 109-119.

4. Harris R., Harris P., Routledge N., Naylor J. \& Wilson A. 2006. Plasma glutamine concentrations in the horse following feeding and oral glutamine supplementation. Equine Veterinary Journal. 36(Suppl): 637-642.

5. Karinch A.M., Pan M., Lin C.M., Strange R. \& Souba W.W. 2001. Glutamine metabolism in sepsis and infection. Journal of Nutrition. 131(Suppl 9): 2535S-2538S.

6. Kellon E.M. 1998. Equine supplements and nutraceuticals. Ossining (NY): Breakthrough Publications, 240p.

7. Kearns C.F., McKeever K.H. \& Abe T. 2002. Overview of horse body composition and muscle architecture: Implications for performance. The Veterinary Journal. 164(3): 224-234.

8. Kearns C.F., McKeever K.H., Kumagai K. \& Abe T. 2002. Fat-free mass is related to one-mile race performance in elite standardbred horses. The Veterinary Journal. 163(3): 260-266.

9. Manso Filho H.C., Costa H.E.C. \& Abreu J.M.G. 2008. Suplementação com aminoácidos modifica a composição corporal e parâmetros sangüíneos de eqüinos idosos. Revista do Conselho Federal de Medicina Veterinária. 43: 9-15.

10. Manso Filho H.C., McKeever K.H., Gordon M.E., Costa H.E.C., Lagakos W.S. \& Watford M. 2008. Changes in 
glutamine metabolism indicate a mild catabolic state in the transition mare. Journal of Animal Science. 86(12): $3424-3431$.

11. Manso Filho H.C., Manso H.E.C.C.C., Ferreira L.M.C., Santiago T.A., Wanderley E.K. \& Abreu J.M.G. 2009. Percentagem de gordura de cavalos criados em região tropical. Acta Scientiae Veterinariae. 37(3): 239-243.

12. Miller A.L. 1999. Therapeutic considerations of L-glutamine: A review of the literature. Alternative Medicine Review. 4(4): 329-248.

13. Parry B. 2003. Normal clinical pathology data. In: Robinson N. (Ed). Current therapy in equine medicine 5. Saint Louis: Saunders, pp.870-886.

14. Rotting A.K., Freeman D.E., Constable P.D., Eurell J.A.C. \& Walling M.A. 2004. Effects of phenylbutazone, indomethacin, prostaglandin e2, butyrate, and glutamine on restitution of oxidant-injured right dorsal colon of horses in vitro. American Journal of Veterinary Research. 65(11): 1589-1595.

15. Salloum R., Duckworth D., Madison J.B., Young M. \& Souba W.W. 1993. Characteristics of l-glutamine transport in equine jejunal brush border membrane vesicles. American Journal of Veterinary Research. 54(1): 152-157.

16. Shimomura Y., Yamamoto Y., Bajotto G., Sato J., Murakami T., Shimamura N., Kobayashi H. \& Mawatari K. 2006. Nutraceutical effects of branched-chain amino acids on skeletal muscle. Journal of Nutrition. 136(2): 529S-530S.

17. Smith D. \& Norris S.R. 2000. Changes in glutamine and glutamate concentration for tracking training tolerance. Medicine and Science in Sports and Exercise. 32(3): 684-689,

18. Stipanuk M.H. \& Watford M. 2000. Biochemical and physiological aspects of human nutrition, Philadelphia: W.B.Saunders Company, 233p.

19. Veiga A., Lopes S., Franciscata C., Oliveira L. \& Merini L. 2006. Valores hematológicos, proteínas plasmáticas totais e fibrinogênio do cavalo crioulo - suas variações em relação ao sexo, idade e manejo. Acta Scientiae Veterinariae. 34(3): 274-279.

20. Wagenmakers A.J.M. 1998. Muscle amino acid metabolism at rest and during exercise: Role in human physiology and metabolism. Exercise and Sports Science Reviews. 26: 287-314.

21. Walsh N.P., Blannin A.K., Clark A.M., Cook L., Robson P.J. \& Gleeson M. 1998. The effects of high-intensity intermittent exercise on the plasma concentration of glutamine and organic acids. European Journal of Applied Physiology. 77(5): 434-438.

22. Welbourne T.C. 1987. Interorgan glutamine flow in metabolic acidosis. American Journal of Phisiology. 253(6 Pt 2): F1069-1076.

23. Westervelt R.G., Stouffer J.R., Hintz H.F. \& Schryver H.F. 1976. Estimating fatness in horses and ponies. Journal of Animal Science. 43 (4): 781-785.

24. Williams M. 2005. Dietary supplements and sports performance: Amino acids. Journal of International Society Sports Nutrition. 2: 63-67. 